\section{ECONOMICS}

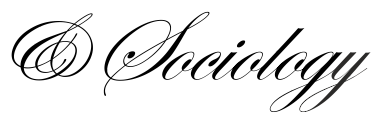

Anita, R. Fedor (2021). Job satisfaction in Hungary - comparative study. Economics and Sociology, 14(2), 331-349. doi:10.14254/2071-789X.2021/14-2/18

\title{
JOB SATISFACTION IN HUNGARY - COMPARATIVE STUDY
}

\author{
R. Fedor Anita \\ University of Debrecen, \\ Nyíregybáza, Hungary \\ E-mail:fedor.anita@ffoh.unideb.bu \\ ORCID 0000-0002-7837-7006
}

Received: June, 2020

1st Revision: April, 2021

Accepted: June, 2021

DOI: $10.14254 / 2071-$

789X.2021/14-2/18

\author{
JEL Classification: J28, I31
}

\begin{abstract}
Since the turn of the millennium, worker's motivation and positive workforce environment are the contributing factors to the development of a global economy. From the perspective of the labor force, employee's job satisfaction, personal well-being and life satisfaction can change the labor market. Studies report that there were significant social and economic changes occurring in European countries, including Hungary. These social and economic changes significantly shaped individual and group value choice and other aspects of a quality life. This study presents a comparative analysis of job satisfaction and work-related attitudes between Hungary and other international nations. While the study was in progress, the COVID-19 epidemic reached Hungary. As a result of COVID-19, new forms of employment developed. The most significant change was the working from home phenomenon. This new system of working significantly transformed the domestic and EU employment opportunities. Also, employee's satisfaction was affected by their working conditions. The study's data analysis aims to identify the underlying emerging trends which will be explored in a future study. According to the results of this research study, the author found that there is a relationship between job satisfaction and a worker's attitude among Hungarian employees. The study results confirm the legitimacy of new theories on human capital.
\end{abstract}

Keywords: satisfaction with job, work value, work attitude, wellbeing, international and Hungarian trends, COVID-19 pandemic.

\section{Introduction}

This study focuses on the post-millennium period and analyzes data collected between 2005 and 2015. The participants who responded as satisfied and fully satisfied with their job showed a slightly decreased percentile over the years. However, approximately three-quarters of the participants responded as satisfied or fully satisfied with their job in both years. In contrast, the opinion of the local (Nyíregyháza) society is less favorable. For statements about external and internal motivations, external motivations, such as a job security and high earnings are the most important factors among all groups of respondents. In terms of Internal factors, such as autonomous search for job opportunity, the socially valued work, and the post materialist work values, such as one's work is personally interesting and the person has an altruistic motivation to work, were the most important factors in 2005. 
In this study, the author will present the changes in job satisfaction issues in Hungary through the data of Eurotstat (2018) and Eurofound (2020) along with the Hungarian databases. Based on these data, the author will present the general satisfaction indicators of the V4s and European countries.

After the general presentation of the international satisfaction indicators, the characteristics of work attitude will be described on the basis of the latest Hungarian data which is compared with the municipality's (one of the most disadvantaged counties in Hungary-Nyíregyháza) survey result. This region is noteworthy because it represents three counties - two are members of the international federation, while the situation of Ukraine is changing. This is an important factor because Szabolcs-Szatmár-Bereg county is located on the eastern border of the European Union.

The questionnaire data collection of this paper drew from the representative samples at three different times. The Hungarian survey questionnaires were selected from the International Social Survey Program (ISSP) of 1989, 1997, 2005 and 2015. This paper presents the analysis of the 2005 and 2015 databases. The independent data collection took place in Nyíregyháza in 2018. Since 2008, the Quality of Life Research Team has assessed the quality life of the inhabitants in Nyíregyháza every other year. The assessment has 7 or 8 dimensions. As a member of the research team, the author of this paper examines economic activity, employment and unemployment issues. Some questions used by the ISSP Work Orientations were considered to be important for local specificities. Thus they were added to the 2018-2019 questionnaires in order to compare the latest data. The ISSP Work Attitude Surveys have been implemented in all Visegrad countries, including Poland in 2015.

While the research study was in progress, social and economic changes occurred in Hungary, European countries and global nations. These phenomena significantly influenced and shaped individuals' and groups' values and quality of life. This is the reason why the analysis of this study is important and substantial. The goal of this study is to map out the changes in work-related attitudes, individuals' perception of job satisfaction, and in what way, the opinions of the regional characteristics have changed.

The first part of this article will present the theoretical framework of job satisfaction and introduce the outcomes of previous research study. The changes in the Hungarian's job satisfaction will be followed by introducing the differences and similarities between the average of Hungarian population and the special work-attitude of the local society. SPSS statistical software was used to evaluate the data.

\section{Literature review}

\subsection{Work as value}

Work has a central role in the society, in the economy and in the individual's life. Work is a means of satisfying needs, a part of culture, a form of social participation, the basis of social embedding.

As a result, the concept of work value has a very diverse, extended meaning. This study highlights some of these attributes. Security is the most important feature, which includes all the factors listed below. Paid work performed in the workplace, recognized with wages and services, means security in modern societies. Primarily, because income from work provides basic living conditions; this is the reason why work is an important element of people's self-esteem (R. Fedor, 2018; Móré, 2018). Thus, work-related values are parts of the overall value system. Additionally work occupies a central place in a person's life and has an 
impact on the quality of life, it is closely related to other personal values (Wuthnow, 2008; Jin, Rounds, 2012).

The income from work together with the social environment provided by the workplace help people to participate in activities that are common to the majority of the society. Unemployed people, on the other hand, have to face with the lack of work-related conditions like basic services and benefits (social insurance). The lack of income, even if indirectly, has an impact on the school performance of the children living in such families.

According to Coleman (1996), one of the three components of the family background is financial capital including the income and the wealth situation of the family. It supports the performance by providing a source for the purchase of tools and services that help children achieve better school performance (R. Fedor and Toldi, 2016).

However, work and the income deriving from work greatly contribute to the quality of life of people and families. They influence their opinion on self-rated subjective health status (Jávorné et al., 2018) and determine the physical and mental well-being (Clark \& Oswald, 1996). Workplace is social space, as the social support system of the workplace significantly influences people's well-being in workplaces and thus has an impact on their work ethic.

It can be stated that work has a beneficial, positive effect on the individuals' sense of well-being (Cannas et al., 2019; Libicki \& R. Fedor, 2020; Fernández Puente \& SánchezSánchez, 2021).

Knowing more about job satisfaction has an increasingly important role in the context of studies exploring subjective well-being, health status, happiness, workplace engagement, and the effects of workplace stress. It also shows that job satisfaction research is a multidisciplinary research field, as it also has psychological, sociological and economic implications. While describing the theories, the focus is on the latter two ones.

A significant part of the previous studies place the job satisfaction of certain occupational groups in the centre of their research, and, in this context, they focus on leaving the career. From this aspect, most Hungarian and international researchers like Betlehem (2012), Németh (2013) and Deutsch et al. (2015) study health care workers, especially nurses.

Another research area focuses on workplace stress. In Hungary, a separate research team deals with this topic: the Workplace Stress and Stress Management Research Team at Semmelweis University, led by Stauder Adrienne.

An international comparative study was conducted by Medgyesi and Róbert (2000). They analyzed the issue of satisfaction based on the data of reference groups. They found that women, people with higher earnings, managers and the self-employed were more satisfied with their jobs. Differences in the individual's work value, in the characteristics of the current work place, or physically and mentally stressful work have negative effects on satisfaction. Their results show that good personal relationship with colleagues increases the level of satisfaction.

Research studies focusing on labor market generational differences assume that employees in younger age groups are less committed to certain "traditional" labor market values compared to the hard-working baby boomer generation. In connection with this topic, Hajdu and Sik (2016) sought to answer if differences in characteristics in attitudes to work were related to time, age or date of birth. Their results show that "instead of generational differences, it is worth talking about generational similarities in terms of work-related values." (Hajdu \& Sik, 2016: 415) All this confirms the global presence and significance of the society of work. 


\subsection{Theories}

Literature on job satisfaction contains different theories and methods of measurement. Job satisfaction is studied from different aspects, however, these aspects still show some similarities. The possible discrepancies in the theories depend on what discipline serves as the basis of their approach to the scientific issue, and what external and internal, organizational and person-dependent indicators are taken into account in the evaluation model.

Sociologists Medgyesi and Róbert (2000) as well as Hajdu and Sik (2016) focus mostly on what pattern job satisfaction shows in the context of different stratification variables, as well as certain social (demographic) groups and value choices. Since the 1970s, the range of research studying employment and labor market generation differences has been very wide, both in the study of societal organizations and in the field of management science (Hajdu \& Sik, 2016). Studying the balance between work and privacy, and assessing the impact on self-rated health status may be a new aspect of health sociological research. This field has hardly been studied, however, it may be an important research topic for the future.

Research studies related to economy, study job satisfaction as a balance of investment in human capital and its return.

Among the representatives of classical economics, Smith was the first to empirically study how investing in human capital and skills usable in the labor market shapes the income and the wage structure. In economic studies, the emphasis is on the relationship between investment result and investment/cost benefit. According to Locke (1976), the values of the employees influence their job satisfaction, which depends on the extent to which workplace factors meet the employees' expectations. In addition to the increase in income, better and less harmful working conditions, more comfortable work, and increased leisure time can be interpreted as the return on higher education. These are the external or additional yields of education (Locke, 1976; Rosen, 1998).

The study of the relationship between the investment and the return for the development of the human capital rests on microeconomic foundations in economics, the sociological aspect follows the practice of status acquisition models. The fundamental difference between economic and sociological approaches is the following: while economics studies the investment/return relationship within an objective, material framework, in sociology the individual's subjective satisfaction indicators also appear as explanatory variables (R. Fedor, 2015). Researching the individual's subjective satisfaction is another challenge for researchers.

If safety has become the most important factor in the evaluation of the job, it may significantly influence the adaptation of the employee to job retention and perhaps a lower satisfaction threshold. If this assumption can be proven, then the aspects of the study need to be expanded.

\subsection{Models}

One way to survey job satisfaction is the Herzberg's two-factor model based on Maslow's general hierarchy of human needs. According to this, the satisfaction is determined by hygienic (external) factors and (internal) motivators. Herzberg classified working conditions, leadership style, wages, and workplace relationships as hygienic factors. Meeting hygienic needs is not a direct consequence of satisfaction. Rather, their lack causes dissatisfaction, however, it does not motivate them to perform better. Higher needs were listed as motivators. In his opinion, these internal motivational factors, like recognition, opportunity for advancement, professional development, responsibility, and how interesting the work is determine satisfaction the most. That is, if the employee is motivated with the motivators, 
they will be more creative, they will perform more effectively, and thus their satisfaction will increase (Herzberg, 1968).

Warr, in his vitamin model, identified each workplace factor with vitamins "C," and "E," and "A" and "D". Vitamins "C" and "E", that is salary, social position, physical security are not harmful even in large quantities either, while the variety of work, the degree of control, the amount of the required skills, the extent of the interpersonal relationships represented by vitamins "A" and "D", can be toxic in large quantities, of course in the context of the relationship between the employee and the workplace (Warr, 1987).

Warr (1987) regards job satisfaction as an indicator of well-being in workplace, in addition to work-related anxiety and emotional exhaustion. These characteristics are greatly influenced by work-specific autonomy, workplace requirements, and workplace social support.

According to Strauss's model, work can be incentive and not incentive. The employee's orientation to work can be extrinsic (asset-type) orientation, when work is seen as a tool to achieve goals outside work to meet the needs of the employees, and intrinsic (expressive) orientation, when work is an end in itself, a source of expressing hidden abilities (Strauss, 1974).

In summary, the employee's satisfaction is determined by the combined presence of several factors: the social recognition of the job, wages, working conditions, opportunities for promotion, control, contact with employees, opportunities for working independently, the role of the worker in the organizational hierarchy and the possibility of influencing his or her own work, as well as socio-demographic and socio-cultural factors, individual life goals and aspirations. They together have an impact not only on job satisfaction but also on life satisfaction in general.

\section{Hungarian labor market processes}

The employment situation in Hungary has shown an increasingly favorable picture recently, although the way to reach this level has not been easy. Two difficult periods characterize the Hungarian labor market processes at the time of the regime change.

During the period of the regime change, dramatic processes began in the labor market. As a result of the political and economic changes in the early 1990s, the employment rate of both men and women dropped drastically, which led to an explosive increase in long-term unemployment and to the growth in the number of inactive people. Following the change of regime, as a result of the transformation in the market economy, the employment in Hungary dropped to approximately its three quarters in the early 1990s, which mainly affected the employees in the heavy and construction industries.

At the turn of the millennium, the Hungarian labor market was characterized by duality. While the proportion of the registered unemployed was relatively low by international comparision, the employment rate also stagnated at a low level. However, the really big problem was the number of the unemployed people who were not looking for job or were not registered for various (education, health, ethnicity, geography, etc.) reasons (Frey, 1997).

The second employment crisis was triggered by the global financial crisis in the second half of 2008, which turned into a general economic crisis by 2009 , resulting in a decrease in employment and a consequent sharp rise in the number of the unemployed. The labor market recession hit the Hungarian regions in different ways. The impact of the crisis hit first and to the greatest extent the regions that had been in more favorable economic and labor market conditions and where the employment had been higher. The number of the unemployed was 421,000 in average in 2009, which was 92,000 (27.8\%) more than in 2008. According to a labor force survey conducted by the Central Statistical Office, the last time 
when the situation was similar, was in 1993. The unemployment rate for people who are 15 to 74 rose from $7.8 \%$ to $10.7 \%$ in one year. In 2010, according to the Labor Force Survey (MEF), the decline in the number of the employees stopped, the growth in the number of the unemployed slowed down (KSH 2009), but actually the labor market recovered only in 2013. Based on the latest statistical data, the situation in Hungary is very favorable. In 2019 the unemployment was $60.8 \%$ and the unemployment rate was $3.4 \%$ for the 15 to 74 year old age group.

The unemployment in Hungary, similarly to the international trends, is characterized by a high degree of territorial differentiation. After the regime change unemployment affected the different parts of the country to varying degrees, and the inequality proved to be persistent. The proportion of the unemployed is the highest among young adults, among those with low level of education, among the inhabitants living in small towns, and in the Roma ethnic groups (Bánfalvy, 2002).

People with the lowest level of education generally live in the worst-off counties, which hampers the reduction of the territorial inequalities. According to national comparison, in Szabolcs-Szatmár-Bereg county the amount of education for 25-50 year old individuals is the worst in the country (Varga, 2015). Szabolcs-Szatmár-Bereg county belongs to the Northern Great Plain region and it is the county where the 2018 survey was conducted. The consequence of the worst educational level causes one of the biggest problems of today's society and economy: low level education of the young people in the cumulatively disadvantaged areas, and the consequent lack of labor market skills (Láczay, 2017).

On the basis of the socio-economic processes that started from the regime change up to the present day, the following employment / labor market periods can be distinguished in Hungary:

1. From 1989/90 up to 1993 - employment crisis I: The regime change and the transition to the market economy greatly shook the employment and social security.

2. From 1994 to 2000 - period of transition: Labor market processes are characterized by a slow but steadily improving trend.

3. From 2001 to 2007 - first rising period: In this period the employment situation improves, with the accession to the European Union the repertoire of the active tools promoting labor market integration and the possibility of its financing expand.

4. From 2008 to 2010 - period of employment crisis II: The financial crisis from the United States reaches the countries of Europe. The unemployment rate reaches the indicators of the period following the regime change.

5. From 2011 to 2019 - second rising period: The employment level is rising, mainly as a result of the responses given by the policy to the general economic crisis.

Thus it can be clearly seen that the databases to be analyzed contain data on the two rising periods, when, the labor management showed its more open, development-ready "face".

However, in order to evaluate these periods, it must be taken into account that the periods of the socio-economic processes have also been reorganized by the international and the Hungarian political events. The most important event is that Hungary became a member of the European Union in 2004, where the more intensive relationship with the foreign economy has a great impact on the investments and on the Hungarian labor management.

2019 is the last year that data on Hungarian marketing is available, however, 2020 might be the beginning of a new period due to the COVID 19 pandemic. Whatever the future brings, the experience and good practices of the past years cannot be forgotten. 


\section{Job satisfaction in international comparison}

Before exploring the job satisfaction situation in Hungary, it is worth reviewing the international situation. The figure below shows the results of the ISSP $(2005,2015)$ data collection. It should be noted that Slovakia and Poland did not participate in the 2005 survey, so we can make a comparison for the Czech Republic and Hungary in the period under review, while from 2015 we have data from all member states of the Visegrad Four. It can be seen that in 2005 and 2015 the satisfaction of Czechs was more decisive than that of Hungarians, moreover, their positive opinion about work increased (by 4.5\%), while among Hungarian respondents there was a slight decrease in the ratio of satisfied and fully satisfied (1.2\%). Focusing on 2015, we find that Slovaks had the most favorable job satisfaction (83.0\%), followed by Czechs (81.7\%), Hungarians (72.9\%) and finally Poles (70.7\%).

Table 1. Job satisfaction in the V4 countries in 2005, 2015

\begin{tabular}{ccccccccc}
\hline & \multicolumn{1}{c}{ Czech Republic } & \multicolumn{2}{c}{ Hungary } & \multicolumn{2}{c}{ Slovakia } & \multicolumn{2}{c}{ Poland } \\
\hline & 2005 & 2015 & 2005 & 2015 & 2005 & 2015 & 2005 & 2015 \\
& $\mathrm{~N}=706$ & $\mathrm{~N}=816$ & $\mathrm{~N}=469$ & $\mathrm{~N}=564$ & $\mathrm{~N}=$ n.d. & $\mathrm{N}=601$ & $\mathrm{~N}=$ n.d. & $\mathrm{N}=913$ \\
\hline not satisfied at all & 0,8 & 1 & 3,0 & 3,2 & n.d. & 0,3 & n.d. & 1,6 \\
\hline not satisfied & 6,4 & 4,2 & 3,0 & 4,6 & n.d. & 4,8 & n.d. & 6,4 \\
\hline $\begin{array}{c}\text { partly satisfied, } \\
\text { partly not }\end{array}$ & 15,7 & 13,1 & 19,6 & 19,3 & n.d. & 11,8 & n.d. & 21,2 \\
\hline satisfied & 65,4 & 65,9 & 39,4 & 35,5 & n.d. & 69,9 & n.d. & 65,4 \\
\hline fully satisfied & 11,8 & 15,8 & 34,9 & 37,4 & n.d. & 13,1 & n.d. & 5,3 \\
\hline $\begin{array}{c}\text { satisfied and fully } \\
\text { satisfied total }\end{array}$ & 77,2 & 81,7 & 74,3 & 72,9 & n.d. & 83 & n.d. & 70,7 \\
\hline
\end{tabular}

Source: ISSP 2005, 2015.

One dimension of Eurostat's 2013 and 2018 quality of life surveys was job satisfaction. As the methodology for measuring satisfaction differs from the methodology for ISSP, we cannot compare the results of the two databases, but we can see how job satisfaction developed in 2018 compared to 2013. Unlike the classification shown in Table 1, Eurostat measured satisfaction on a scale of $0-10$. They defined values 0 to 5 as low satisfaction, values 6 to 8 as medium satisfaction, and values 9 to 10 as high or complete satisfaction. The figures below show these values. Based on the results, we can conclude that the proportion of the most satisfied and dissatisfied workers among the countries surveyed also decreased on average by 2018 , which means that opinions have shifted towards the "moderately satisfied" category, which embodies the intermediate position. Of the $\mathrm{V} 4 \mathrm{~s}$, this finding is not true for Slovakia alone. However, it can also be seen that in Estonia (+ 6.7\%), Ireland $(+10.1 \%)$, Spain $(6.2 \%)$ there was a statistically significant increase in the proportion of very satisfied and a significant decrease in Luxembourg (-7.7\%). and among Polish (-4.3\%) respondents.

Due to the COVID-19 pandemic, working conditions have changed significantly. As a result of epidemiological measures, personal presence has, in many cases, been replaced by teleworking. Especially Hungary, where telework was not a popular form of employment, but this seems to be changing, according to V. Balla (2021). Teleworking means that workers have not traditionally performed their daily tasks from their place of work, but away from there, from their homes, using infocommunication tools (Olson 2003), in sectors where the nature of the work allowed it. In the Eurofound (2020) survey on Living, Working and COVID-19, respondents were asked about, among other things, their work situation, work-life balance, and the use of telecommuting (home office). An evaluation of the home office found that most European workers were satisfied with the work they did from home. There were, of 
course, differences in the degree of agreement; telework was most valued in Finland and Austria, and least in Poland and Greece. At the same time, there are problems of work organization, engagement, and other subjective problems that can be increased in the community.

Table 2. Job satisfaction in the EU27 2013, 2018

\begin{tabular}{lcccccc}
\hline & \multicolumn{3}{c}{ Job satisfaction 2013} & \multicolumn{3}{c}{ Job satisfaction 2018 } \\
\hline GEO/INDIC_WB & High & Medium & Low & High & Medium & Low \\
\hline European Union - 27 countries (from 2020) & 24,3 & 56,6 & 19,1 & 24,6 & 58,5 & 16,9 \\
\hline Austria & 42,2 & 47,6 & 10,2 & 40,2 & 50,4 & 9,4 \\
\hline Belgium & 23,0 & 68,5 & 8,5 & 23,5 & 67,2 & 9,3 \\
\hline Bulgaria & 16,1 & 36,1 & 47,7 & 18,2 & 45,3 & 36,6 \\
\hline Croatia & 25,6 & 49,0 & 25,4 & 25,1 & 50,4 & 24,5 \\
\hline Cyprus & 28,2 & 51,8 & 20,0 & 25,0 & 57,9 & 17,1 \\
\hline Czechia & 29,6 & 51,4 & 19,0 & 30,1 & 52,5 & 17,4 \\
\hline Denmark & 44,4 & 46,4 & 9,2 & 39,6 & 44,8 & 15,6 \\
\hline Estonia & 26,6 & 55,1 & 18,4 & 33,3 & 53,6 & 13,1 \\
\hline Finland & 40,8 & 54,6 & 4,7 & 41,4 & 53,2 & 5,3 \\
\hline France & 20,0 & 64,7 & 15,4 & 20,7 & 65,0 & 14,4 \\
\hline Germany (until 1990 former territory of the FRG) & 25,0 & 50,7 & 24,3 & 25,0 & 53,1 & 21,9 \\
\hline Greece & 14,0 & 48,3 & 37,7 & 12,1 & 58,3 & 29,6 \\
\hline Hungary & 23,0 & 55,7 & 21,3 & 22,6 & 57,2 & 20,2 \\
\hline Ireland & 28,3 & 51,7 & 20,0 & 38,4 & 50,2 & 11,5 \\
\hline Italy & 20,2 & 62,2 & 17,6 & 18,9 & 67,9 & 13,2 \\
\hline Latvia & 25,8 & 56,9 & 17,3 & 27,5 & 57,3 & 15,2 \\
\hline Lithuania & 29,6 & 55,4 & 15,0 & 26,0 & 50,1 & 23,9 \\
\hline Luxembourg & 30,4 & 55,1 & 14,5 & 22,7 & 62,4 & 14,9 \\
\hline Malta & 27,2 & 59,7 & 13,1 & 28,4 & 58,2 & 13,4 \\
\hline Netherlands & 22,9 & 71,7 & 5,4 & 20,8 & 71,4 & 7,8 \\
\hline Poland & 32,0 & 48,2 & 19,8 & 27,7 & 54,1 & 18,1 \\
\hline Portugal & 24,5 & 50,4 & 25,1 & 23,7 & 53,9 & 22,4 \\
\hline Romania & 20,4 & 61,6 & 18,0 & 21,6 & 61,3 & 17,1 \\
\hline Slovakia & 29,2 & 48,5 & 22,3 & 27,7 & 46,8 & 25,4 \\
\hline Slovenia & 29,1 & 51,5 & 19,3 & 30,3 & 54,3 & 15,4 \\
\hline Spain & 19,4 & 59,1 & 21,5 & 25,6 & 59,4 & 14,9 \\
\hline United Kingdom & 28,0 & 49,6 & 22,4 & 29,0 & 51,5 & 19,5 \\
\hline Sources & & & & & & \\
\hline
\end{tabular}

Source: Eurostat, Percentage of the population rating their satisfaction as high, medium or low by domain, sex, age and educational attainment level [ilc_pw05]. 


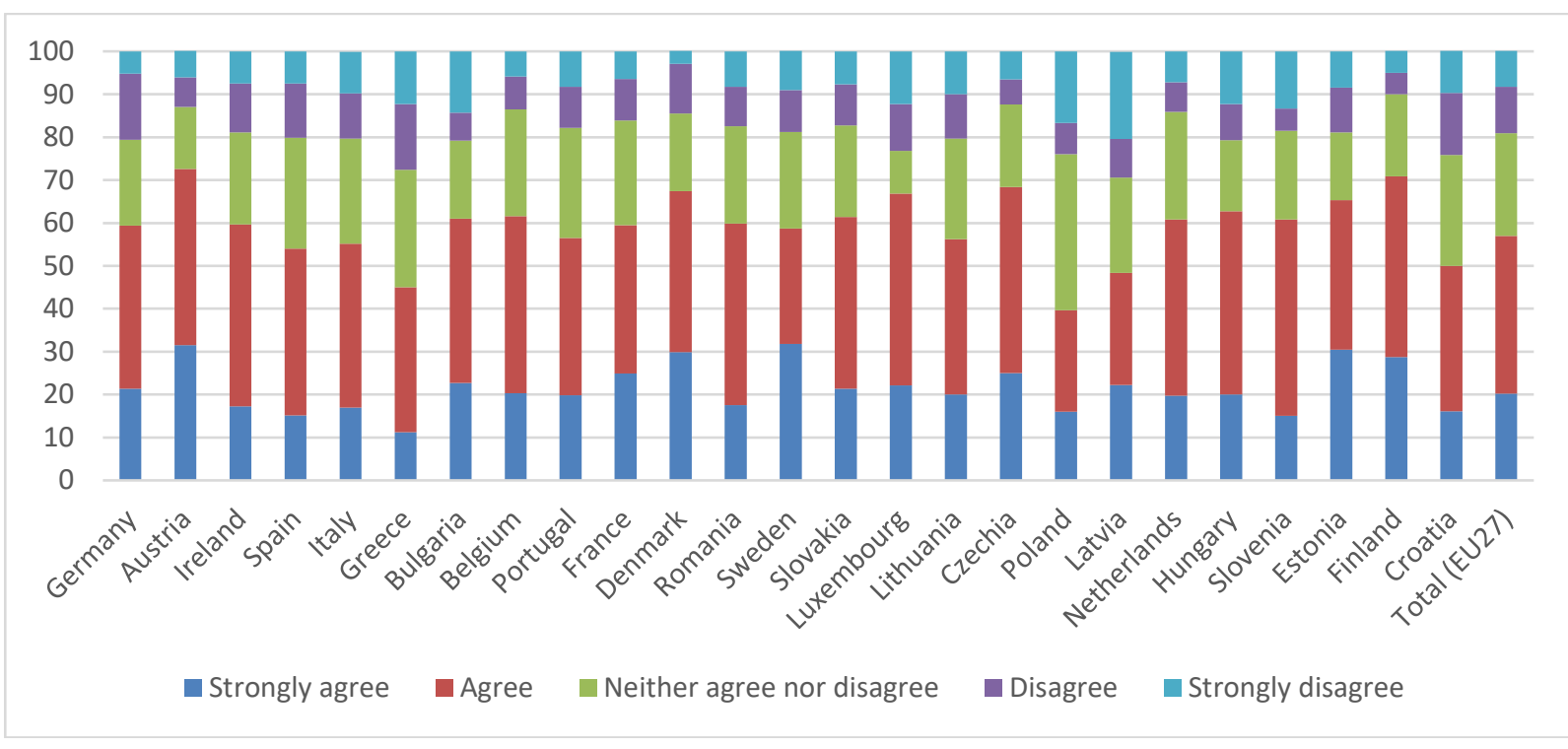

Figure 1. Overall, I am satisfied with my experience of working from home by country, 2020 Source: Eurofound (2020) http://eurofound.link/covid19data.

It is conceivable that the experience of working from home during the COVID-19 crisis will lead to the partial survival of telework as the crisis eases. The results of the study show that this would be supported by the majority of responding employees.

\section{Job satisfaction in Hungary}

\subsection{Methodological approach}

The following part of the paper presents the characteristics of the Hungarian pattern of job satisfaction, focusing on the tendencies of the above-mentioned economic and social relations after the turn of the millennium. The latest national data (2015) will be compared with the results of the population living in the municipality of Szabolcs-Szatmár-Bereg county (2018). For analysing the 2005 and 2015 periods, the ISSP database is used. From this database the Hungarian data are selected (Table 1). The local data were collected by the Quality of Life research team in Nyíregyháza, in 2018, involving 478 respondents. In the empirical work in Nyíregyháza, the research group worked with the address list provided by the Central Office of Public Administration and Electronic Public Services (main address list: 1000 households; 500 additional titles). The data were recorded with the involvement of interviewers. As a result of the data cleansing, 500 of the 541 questionnaires processed remained actually usable in the database. Due to the high number of non-responses, matrix weighting was performed for gender, age and education, thus eliminating biases. (Fábián et al., 2018).

SPSS 25 for Windows was used for the analysis. With the help of this software univariate and multivariate analysis techniques were applied. The univariate analysis technique provided a comprehensive picture of the database, the application of the multivariate analysis technique made it possible to explore the relationships between two or more variables. One of the most commonly used forms of the multivariate analysis was the cross-tab analysis. Pearson's $\chi^{2}$ statistics has been used to show the relationship between the two variables. 
Work-related values and job satisfaction were analysed on the basis of the 2016 methodological recommendation of Hajdu and Sik by including two independent variables. One of the variables was the judging the importance of work. The question "How satisfied are you with your work?" used in the ISSP and in the Nyíregyháza's Quality of Life Panel Survey questionnaires could be answered on a five-point Likert scale.

The other important analytical aspect was built around Herzberg's two-factor model. This aspect focused on how respondents felt about some of the statements in the group of hygienic or external incentives (good pay, safe workplace, good schedule) and internal motivators (how interesting and how useful the work is, helping others, independent decision about certain characteristics of work).

\subsection{Conducting research and results}

The number of persons in the national sample serving as the basis of the analytical work was 1,011 in 2005, 1,031 in 2015, and it was 453 in Nyíregyháza in 2018. The average age was 49-50 on the basis of the 2005 and 2015 databases, an in 2018 it was 47.4.

Table 3. The general sociodemographic and sociocultural characteristics of the three databases

\begin{tabular}{lccc}
\hline & $\begin{array}{c}2005 \mathrm{~N}=1011 \\
\text { (national) }\end{array}$ & $\begin{array}{c}2015 \mathrm{~N}=1031 \\
\text { (national) }\end{array}$ & $\begin{array}{c}2018 \mathrm{~N}=453^{1} \\
\text { (local) }\end{array}$ \\
\hline \multicolumn{1}{c}{ Eduational level } & & & 16.4 \\
\hline $\begin{array}{l}\text { Maximum 8 classes of the } \\
\text { elementary school (\%) }\end{array}$ & 27.6 & 20.9 & 21.0 \\
\hline $\begin{array}{l}\text { Vocational school, Secondary } \\
\text { technical school (\%) }\end{array}$ & 25.6 & 29.6 & 35.9 \\
\hline Final exam in high school (\%) & 32.0 & 37.1 & 26.7 \\
\hline Higher education (\%) & 14.8 & 12.5 & 44.4 \\
\hline \multicolumn{1}{c}{ Gender, age, income } & & & 56.6 \\
\hline Fale (\%) & 42.6 & 42.3 & 47.4 \\
\hline Avemale (\%) & 57.4 & 57.7 & 50.04 \\
\hline
\end{tabular}

Source: ISSP 2005, 2015, Nyíregyháza Életminősége (Quality of Life of Nyíregyháza) 2018.

All the three surveys are characterized by a slightly stronger willingness of women to respond. The largest difference was found in the education-related indicators. Comparing the three samples, it can be seen that the level of education of the respondents in Nyíregyháza is higher than the average level of education of the two national surveys. This partly contradicts the Hungarian results, as according to the latest comparative data, the distribution of the education in the 25-50 age group is the worst in Szabolcs-Szatmár-Bereg county (Northern Great Plain region), where the 2018 study was conducted (Varga, 2015).

In addition to the geographical location of the region, Szabolcs-Szatmár-Bereg county, which belongs to the Northern Great Plain region, is one of the counties with the highest unemployment rate. The reason of the high education level in the 2018 sample might be because the data collection took place at the county seat, which functions as a center in the socio-economic relations of the county and the region.

\footnotetext{
${ }^{1}$ In the local (Nyíregyháza) sample, unlike the national data collection, we interview a total of 541 people, of whom 453 answered this question.
} 
This is where the employers, who basically require employees with high qualification, are concentrated. It is also known that the willingness of the more highly qualified population to respond is generally more favorable than that of the less educated. Anyway, the respondents with high education level are over-represented in the Nyíregyháza sample. This fact must be taken into account while explaining the results and correlations.

On the basis of the most decisive question of the questionnaire: "How satisfied are you with your work?", the following results emerged. Opinions about working conditions reveal the image of a somewhat satisfied Hungarian society. Between 2005 and 2015, the proportion of those who were satisfied and fully satisfied with their work slightly decreased, but even so, nearly three-quarters of respondents indicated this category in both years. In comparison, $60.2 \%$ of the local (Nyíregyháza) society belongs to the "satisfied" and "fully satisfied" groups.

From the listed options, the "satisfied" version was chosen by the most of the respondents in 2005 and 2018, however, in 2015, the proportion of the "fully satisfied" responds was the highest. Interestingly, the opinion of the respondents in 2005 and 2015 shows a slight difference between the satisfied and fully satisfied categories. In contrast, the local society thinks about job satisfaction in a more characteristic way.

Clear dissatisfaction was expressed by $6 \%$ and $7.8 \%$ of the respondents in the two national surveys. A higher proportion (12.9\%) of the members of the local society believe that they are dissatisfied with their work (Table 4).

In the national data there was not a significant relationship between satisfaction and age or gender in $2005(\mathrm{p}=<0.102 ; \mathrm{p}=<0.304)$ or in $2015(\mathrm{p}=<0.689 ; \mathrm{p}=<0.110)$.

The job satisfaction of the inhabitants in Nyíregyháza is not shaped by the gender (male/female) variable $(\mathrm{p}=<0.097)$ either, compared to the age variable $(\mathrm{p}=<0.000)$. Those who were completely satisfied belong to the 20-29, 30-39, and 60+ age groups. In this respect, the opinion of the population between the age of 50-59 and 40-49 was less favorable.

Table 4. How much are you satisfied with your job? (\%)

\begin{tabular}{cccc}
\hline & $\begin{array}{c}2005 \mathrm{~N}=469 \\
\text { (national) }\end{array}$ & $\begin{array}{c}2015 \mathrm{~N}=564 \\
\text { (national) }\end{array}$ & $\begin{array}{c}2018 \mathrm{~N}=354 \\
\text { (local) }\end{array}$ \\
\hline not satisfied at all & 3.0 & 3.2 & 3.9 \\
\hline not satisfied & 3.0 & 4.6 & 9.0 \\
\hline partly satisfied, partly not & 19.6 & 19.3 & 27.0 \\
\hline satisfied & 39.4 & 35.5 & 39.1 \\
\hline fully satisfied & 34.9 & 37.4 & 21.1 \\
\hline satisfied and fully satisfied total & 74.3 & 72.9 & 60.2 \\
\hline
\end{tabular}

Source: ISSP 2005, 2015, Nyíregyháza Életminősége (Quality of Life of Nyíregyháza) 2018.

Opinions on job satisfaction indicate a significant relationship with the variables of the educational qualification in $2015(\mathrm{p}=<0.000)$ and $2018(\mathrm{p}=<0.000)$ (Table 5).

According to national data, people with the highest qualifications are the most satisfied (86.3\%). They are followed by people with a high school degree (77.2\%), with a vocational school degree $(66.5 \%)$, and with a maximum primary school education $(57.7 \%)$. Thus, it can be concluded, that the dissatisfaction (14.8\%), and the proportion of the respondents who are neutral $(27.7 \%)$ are the highest in the latter group.

Local data show a partially similar pattern. People with higher education are the most satisfied, their 61.4 percent belong to the satisfied and fully satisfied groups. They are followed by the group of respondents with vocational education $(61 \%)$ and the respondents with high school degree $(58.2 \%)$. People who completed maximum 8 classes of primary 
school are sharply separated in this respect. Among them, the satisfaction rate is $31.3 \%$, and the percentage of the dissatisfied and the completely dissatisfied is $35.7 \%$. As a comparision, $14.6 \%$ completed vocational school, $8.7 \%$ has a high school degree and 5\% of those with university eduation were dissatisfied.

Comparing the national (2015) and local results, although almost the same trend can be seen, marked differences could be noticed regarding the detailed opinions. Basically both samples show satisfied employee attitude (except for the local employees with the lowest qualification), it is clear that the national population is much more satisfied. Among them, with the exception of those with vocational education, the satisfaction rate is on average $20 \%$ higher in each group.

It is also clear that the dissatisfaction of the local respondents with low educational level exceeds more characteristically. This group includes $45.7 \%$ of the respondents with no more than primary education and $14.4 \%$ of those with vocational education. This is far beyond the percentage of the similarly educated Hungarian people $(14.8 \%$ and $9.0 \%$,). Another striking data is the very high distribution of the neutral local respondents and the local respondents who marked the "partly satisfied partly not" answer category.

Table 5. How satisfied are you with your job? (\%)

\begin{tabular}{|c|c|c|c|c|c|c|c|c|}
\hline \multirow[b]{3}{*}{$\begin{array}{c}\text { How satisfied are } \\
\text { you with your } \\
\text { job? }\end{array}$} & \multicolumn{8}{|c|}{ School qualification } \\
\hline & \multicolumn{4}{|c|}{2015 (national) } & \multicolumn{4}{|c|}{2018 (local) } \\
\hline & $\begin{array}{l}8 \text { classes } \\
\text { of } \\
\text { elementary } \\
\text { school }\end{array}$ & $\begin{array}{l}\text { Vocational } \\
\text { school } \\
\text { without } \\
\text { final exam }\end{array}$ & $\begin{array}{l}\text { High } \\
\text { school } \\
\text { Final } \\
\text { exam }\end{array}$ & Diploma & $\begin{array}{l}8 \text { classes } \\
\text { of } \\
\text { elementary } \\
\text { school }\end{array}$ & $\begin{array}{l}\text { Vocational } \\
\text { school } \\
\text { without } \\
\text { final exam }\end{array}$ & $\begin{array}{l}\text { High } \\
\text { School } \\
\text { Final } \\
\text { exam }\end{array}$ & Diploma \\
\hline $\begin{array}{c}\text { not satisfied at } \\
\text { all }\end{array}$ & 2.0 & 4.7 & 1.9 & 2.4 & 17.1 & 2.4 & 2.6 & 3.6 \\
\hline not satisfied & 12.8 & 4.3 & 4.4 & 2.4 & 28.6 & 12.2 & 6.2 & 9.4 \\
\hline $\begin{array}{l}\text { partly satisfied } \\
\text { partly not }\end{array}$ & 27.7 & 24.5 & 16.5 & 8.9 & 22.9 & 24.4 & 33.0 & 25.7 \\
\hline satisfied & 29.8 & 39.7 & 36.7 & 25.5 & 20.0 & 43.9 & 41.7 & 39.9 \\
\hline fully satisfied & 27.7 & 26.8 & 40.5 & 60.8 & 11.4 & 17.1 & 16.5 & 21.5 \\
\hline
\end{tabular}

Source: ISSP 2015, Nyíregyháza Életminősége (Quality of Life of Nyíregyháza) 2018.

The following questions measured how important the statements were to those concerned. Then, in comparison, it was asked if the attributes that were considered important or less important characterize the respondant's present situation e.g. job. For example, first it was asked how important it is to have a secure job, and then it was asked if the respondent's current job is secure (Table 6).

Table 6. The percentage of the answers regarding "secure job"

\begin{tabular}{cccccccc}
\hline \multicolumn{2}{c}{ How important is it for you to have a secure job? (\%) } & \multicolumn{3}{c}{ The respondent has a secure job (\%) } \\
\hline & $\begin{array}{c}2005 \\
\mathrm{~N}=1000\end{array}$ & $\begin{array}{c}2015 \\
\mathrm{~N}=1001\end{array}$ & $\begin{array}{c}2018 \\
\mathrm{~N}=453\end{array}$ & & 2005 & 2015 & $\mathrm{~N}=470$ \\
$\mathrm{~N}=563$ & $\mathrm{~N}=344$ \\
\hline $\begin{array}{c}\text { not important at } \\
\text { all }\end{array}$ & 0.1 & 0.3 & 0.4 & not true at all & 3.8 & 3.2 & 8.6 \\
\hline not important & 0.5 & 1.1 & 1.2 & not true & 13.6 & 7.5 & 7.2 \\
\hline $\begin{array}{c}\text { partly important } \\
\text { partly not }\end{array}$ & 0.7 & 5.7 & 4.5 & $\begin{array}{c}\text { partly true } \\
\text { partly not }\end{array}$ & 26.0 & 34.3 & 16.3 \\
\hline important & 26.4 & 32.5 & 34.9 & true & 41.7 & 38.5 & 42.2 \\
\hline very important & 72.3 & 60.4 & 58.9 & very true & 14.9 & 16.5 & 25.7 \\
\hline
\end{tabular}

Source: ISSP 2005, 2015, Nyíregyháza Életminősége (Quality of Life of Nyíregyháza) 2018. 
Job security was considered important or very important by the respondents in all the three survey years. However, the stability and security of the own job were judged differently both in space and time. The most striking difference is that most of the members of the local society living in a disadvantaged region and county (one in four respondents) stated that it was very true that they had a secure job. During this period, after the regime change, the local elite saved their previous favorable position, and during the period of the generational change, the more educated young people took over the role of their fathers in the stable positions in villages, in family businesses, and in the local administration. (Láczay, 2014)

This result may seem to be surprising, but the educational composition of the local respondents is more favorable compared to the two national databases, that is, they are less affected by the fear of losing their job. It is also supported by the results of the two-sample survey regarding job security. According to it the educational level is the explanatory variable of job security $(\mathrm{p}<=0.001)$. The more qualified the employees are, the more secure they feel. This result confirms the above reasoning. The national opinions for 2005 and 2015 are almost the same. The neutral, hesitant "partly true partly not" category was the highest in 2015. It means one in three Hungarian respondent had the same opinion.

The similar opinions on job security are not surprising, as in modern societies apostrophized as societies of work, work is a central value for providing livelihood. This is the case in some welfare states, and especially in Hungary. In some welfare states the institutionalized welfare, in other ones residual welfare, and in a third type of these states their combination play greater role. Of course, the emphases are concentrated in different ways and places according to social policy principles and values. Residual well-being is more typical to Hungary. Residual principle means that it is basically the duty of the individual to take care of him- or herself.

The primary financial background for care is covered by the income from work and the related benefits. The welfare social system focuses on those who are excluded from the world of work and those who suffer from its disadvantages, keeping the principle of less eligibility in mind. In this sense, the various benefits are developed in a way that it would be less worthwhile to choose a way of living based not on one's own effort, not on work, but on other benefits. In this way, it is understandable that work is a central category for the economically active members of the Hungarian society.

Table 7. How important is it for you personally ...

\begin{tabular}{|c|c|c|c|c|c|c|}
\hline & \multicolumn{3}{|c|}{$\begin{array}{l}\text { "Important, very } \\
\text { important"(\%) }\end{array}$} & \multicolumn{3}{|c|}{$\begin{array}{l}\text { "Not important at all, } \\
\text { not important" (\%) }\end{array}$} \\
\hline & 2005 & 2015 & 2018 & 2005 & 2015 & 2018 \\
\hline ... to have a secure job? & 98.7 & 92.9 & 93.8 & 0.6 & 1.4 & 1.6 \\
\hline ... to have high salary? & 92.8 & 88.4 & 89.7 & 1.0 & 1.8 & 1.0 \\
\hline ... to have an interesting job? & 80.9 & 74.8 & 75.7 & 5.3 & 4.8 & 6.0 \\
\hline ... to have good job promotion opportunities? & 67.5 & 66.7 & 74.9 & 12.9 & 10.9 & 4.4 \\
\hline $\begin{array}{c}\text {... to have a job that you can perform } \\
\text { individually? }\end{array}$ & 72.9 & 67.1 & 71.5 & 9.6 & 9.5 & 7.8 \\
\hline ... to be useful for the society? & 80.4 & 71.5 & 69.2 & 4.5 & 6.5 & 9.1 \\
\hline $\begin{array}{l}\text {... to have a job you can help other people } \\
\text { with? }\end{array}$ & 74.4 & 61.1 & 67.7 & 4.6 & 10.6 & 7.6 \\
\hline $\begin{array}{l}\text {.. to have a job where you can decide which } \\
\text { part of the day and which days to work? }\end{array}$ & 47.6 & 44.1 & 46.1 & 26.2 & 24.5 & 28.5 \\
\hline
\end{tabular}

Source: ISSP 2005, 2015, Nyíregyháza Életminösége (Quality of Life of Nyíregyháza) 2018 
After job security, high earning opportunity is the most preferred category in all the three study years. On average, $90 \%$ of the respondents rated it as important or very important. This is not surprising, as income from work is the basis of livelihood in Hungary. Although "How interesting is your work" was rated third, it is still worth noting that in 2005 this issue was the most important. The slightly more unfavorable assessment in 2015 and 2018 is identified as an accompanying phenomenon of the 2008 financial crisis and regionalism. Assessing the importance of other responses provides a very varied picture in space and time.

Job promotion opportunities were rated on the top (4th) in the local research study. According to this, it is important for three-quarters of the respondents to work in a workplace where job promotion opportunities are favorable. In the other two study years, this value was rated sixth and seventh - although the majority still agrees on the importance of advancing in the workplace hierarchy. The underlying reasons could be revealed by further research. It can be seen that the hierarchy has been consolidated, especially in disadvantaged, small-village settlements, the mobilization opportunities have narrowed. People with low educational level started to appreciate education because they hope they would get a secure job if they had a higher educational level.

Working independently and having the opportunity to determine the work schedule independently indicate a move away from collective work, from mass production, to bring the individual to the fore, and to have a job that is better adapted to the individual's life situation.

The importance of a job that can be performed independently was considered important and very important by $70 \%$ of the respondents. In 2018, it was the fifth most important value for the local society, in 2015 it was again the fifth and in 2005 it was the sixth most important value for the Hungarian society. To determine independently which part of the day they want to perform the work was considered the least important by the respondents in all three study years (average $46 \%$ ).

Having a useful job for the society was very dominant both in 2005 and in 2015, it was the fourth in the rating. However, the differences in the distribution were significant $(80.4 \%$, $71.5 \%$ ). A similar percentage of the local society (69.2\%) could be seen in 2018 , when this value was rated the sixth. The altruistic values were also the strongest in 2005 . Three-quarters of the respondents considered having a job that can help others directly or indirectly important or very important (Table 7 ).

Table 8 . How true are the following statements to your full-time job

\begin{tabular}{ccccccc}
\hline & \multicolumn{3}{c}{ "Very true, true"(\%) } & \multicolumn{3}{c}{ "Not true at all, not true"(\%) } \\
\hline & 2005 & 2015 & 2018 & 2005 & 2015 & 2018 \\
\hline & 56.6 & 55.0 & 68.1 & 17.4 & 10.7 & 15.8 \\
\hline You have a secure job. & 15.1 & 13.6 & 22.9 & 59.5 & 57.6 & 30.8 \\
\hline Your salary is high. & 61.0 & 51.0 & 53.1 & 16.0 & 19.7 & 20.3 \\
\hline The job is interesting. & 14.5 & 17.5 & 26.0 & 61.7 & 59.8 & 45.9 \\
\hline $\begin{array}{c}\text { You have good promotion } \\
\text { opportunities. }\end{array}$ & & & & & & \\
\hline You can work independently. & 69.1 & 60.4 & 71.1 & 8.3 & 15.1 & 7.3 \\
\hline $\begin{array}{c}\text { You can help others with your job. } \\
\text { Your job is useful to the society. }\end{array}$ & 72.5 & 66.5 & 59.4 & 7.3 & 11.0 & 17.8 \\
\hline $\begin{array}{c}\text { Your job gives you possibilities to } \\
\text { develop your abilities. }\end{array}$ & 48.7 & 70.9 & 69.2 & 6.2 & 7.9 & 12.5 \\
\hline $\begin{array}{l}\text { Your job gives you the opportunity } \\
\text { to keep contacts with other people. }\end{array}$ & n.d. & 76.4 & n.d. & n.d. & 8.0 & n.d. \\
\hline
\end{tabular}

Source: ISSP 2005, 2015, Nyíregyháza Életminősége (Quality of Life of Nyíregyháza) 2018.

From Table 8. it can be seen that among the external motivational factors, high earnings and the possibility of advancement characterize the members of the society the least. 
Only very few of the respondents are satisfied with their salaries. In 2005 only $15.1 \%$ and in 2015 only $13.6 \%$ of the respondents said they had high earnings.

The gender variable shows a significant relationship with high earnings in all study years $(2015 \mathrm{p}<=0.018 .2005 \mathrm{p}<=0.028 .2018 \mathrm{p}<=0.035)$. There were statistically fewer men who stated that they were not, or not at all, true to them that they have a high salary. Education also shapes salaries. As expected, the salaries of those with higher education are more favorable (2015 $\mathrm{p}<=0.000 ; 2005 \mathrm{p}<=0.000 ; 2018 \mathrm{p}<=0.000)$.

Although still few, but compared to the national data, more Nyíregyháza residents (one in four) said they had high earnings. Of course, it should be considered that the responses, although determined by macro-level factors, were based on subjective criteria. The definition of what high earnings mean is greatly influenced by what sector of the labor market you work in and the average Hungarian and regional income. Slightly more than half of the respondents had secure, stable job in 2005 and 2015. It seems very unfavorable, especially because the assessment of the importance of job security was above $90 \%$ in each of the three years (close to $100 \%$ in 2005). The local data, which exceeds $68 \%$, differs from the national data. It is also because the majority of the respondents were more qualified. We also found a significant relationship between education in $2015(\mathrm{p}<=0.000)$ and $2018(\mathrm{p}<=0.000)$ and the existence of a job considered stable by the respondent.

As an internal motivational factor, good promotion opportunities were given to few in terms of the two national samples, however, $26 \%$ of the members of the local society had a job where there is an opportunity to move forward in the organizational hierarchy. Working independently is also a privilege of the residents of Nyíregyháza and those participating in the 2005 survey. The average in 2015 is $10 \%$ behind the 2005 data. The social usefulness of the job and the characteristics of "you can help others with your work" were impportant to $66 \%$ and $72 \%$ of the respondents respectively.

Our results show that higher levels of education are predictive variables of workplace progression (2015 $\mathrm{p}<=0.018 ; 2005 \mathrm{p}<=0.006 ; 2018 \mathrm{p}<=0.000)$. The gender variable proved to be significant in 2018 ( $\mathrm{p}<=0.039$ ), with a higher proportion of men reporting working in a workplace where they have the opportunity to progress. Independent work is also the privilege of Nyíregyháza residents and participants in the 2005 survey, from which the 2015 average is $10 \%$ lower The social usefulness of work and the characteristics "you can help others with your work" are true for an average of $66 \%$ and $72 \%$ of respondents, respectively. The importance of helping others is characteristic of women $(2015 \mathrm{p}<=0.067$; $2018 \mathrm{p}<=0.020)$ and respondents with higher education $(2005 \mathrm{p}<=0.000 ; 2018 \mathrm{p}<=0.000)$. Just as the social usefulness of work is closely related to the level of education $(2005 \mathrm{p}<=$ $0.019 ; 2015 \mathrm{p}<=0.000 ; 2018 \mathrm{p}<=0.000)$.

The question arose as to whether individual sociodemographic and cultural factors correlated with the mental characteristics of work performance. The statistical test showed a significant correlation with the educational variable in 2005 ( $\mathrm{p}<=0.087)$, and in 2015 with the educational variable $(\mathrm{p}<=0.000)$ and gender $(\mathrm{p}<=0.032)$. We found that a higher proportion of those with higher education report frequent or continuous mental strain, and that a higher proportion of women never feel mentally stressful or stressful about their work. In the local society, the explanatory power of education was also proved ( $\mathrm{p}<=0.000$ ). Examining the crosstab, however, revealed a very complex picture. A significant proportion of those who indicated the never and almost never options came from among those with up to 8 primary school classes as well as vocational qualifications In contrast, employees with a GCSE and diploma are often stressed. Constantly stressful work mainly affects those with vocational and higher education, presumably those who perform a task burdened by decisionmaking situations, and those commodity groups who are most affected by the lack of job security. 


\section{Conclusion}

The recent study presents the Hungarian results of the changes in job satisfaction and in certain work-related values, focusing on the period after the turn of the millennium. Characteristics of work attitude described on the basis of the latest Hungarian data are compared with the results of a survey conducted in the municipality of one of the most disadvantaged counties in Hungary (Nyíregyháza). The paper is based on three wellcomparable databases. The paper is based on two questionnaire data surveys: the International Social Survey Program conducted the national questionnaire data surveys in 2005 and in 2015, while the the local (Nyíregyháza) questionnaire data surveys were conducted in 2018.

The concept of work value has a very diverse, expanded meaning. The current study focuses on job satisfaction and on the external and internal motivational factors that define satisfaction. These factors are described in Herzberg's two-factor model. Work safety is highlighted from among these factors. Good salary, secure workplace, good schedule were identified as external factors. Internal motivators include how interesting and useful the work is, if it provides help to other peopole, and if there is a possibility for independent decision. The goal of the research was to explore the spatial and temporal differences and similarities in the work-related attitudes.

The opinions about job satisfaction show a somewhat satisfied Hungarian society. It can be seen that between 2005 and 2015, the percentage of those who were satisfied and fully satisfied with their work slightly decreased, but even so, almost three-quarters of the respondents indicated this category in both years. Compared to this, the opinion of the local (Nyíregyháza) society is more unfavorable. The explanation of the very favorable attitude of the respondents in the two national surveys might be that as a result of joining the European Union in 2005, the emergence of the foreign investors absorbed the (cheap) labor force. That is, the beneficiaries of this period were those who had previously been the most affected by the unemployment and with the precarious lifestyle associated with it.

The outstanding employee satisfaction in 2015 is presumably due to the fact that by that time the impact of the 2008 crisis had not yet passed without a trace. The employment crisis related to the 2008 crisis peaked between 2009 and 2010. Additionally in 2015 the Hungarian society was just coming out of this difficulty. The explanation of this high level of satisfaction might be that the employees had previously experienced a fear of the loss of job. This fear transformed the values of the employees; they were satisfied because they had a job. The general dissatisfaction due to regional differences and difficulties is shown in the lower satisfaction level of the local society.

Age is significantly related to the job satisfaction of the local society. Respondents 2029, 30-39, and 60+ are the most satisfied, and those 50-59 and 40-49 are the most dissatisfied. (Data for 2005 and 2015 showed no correlation with age.)

Both in 2015 and 2018, opinions on job satisfaction had significant relationship with the variable of school educational level. According to national data, those with the highest qualifications are the most satisfied and those with the lowest qualifications are the most dissatisfied. Local data show a partially similar pattern. However, the rate of the dissatisfied respondents who completed 8 classes of the primary school is more than twice higher than that of the people who have higher educational level. It should be emphasized that most of the neutral respondents come out of this group. They can be classified as precarious employees.

Job security and high earning opportunities are the most preferred categories in each of the three study years. On average, $90 \%$ of the respondents rated it as important or very important.

Although "How interesting is your work" was rated third, it is still worth noting that in 2005 this issue was the most important. The slightly more unfavorable assessment in 2015 
and 2018 is identified as an accompanying phenomenon of the 2008 financial crisis and regionalism. For statements about external and internal motivations, external motivations/constraints, such as job security, high earnings are the most important for all the respondent groups. Internal factors like the opportunity of having of a job that can be done independently, the social usefulness of work, and the postmaterialist work values like how interesting the work is and the altruistic behavior related to work were the most important in 2005.

Therefore, it can be said that the job satisfaction and the work attitude of the respondents of the three survey years are characterized by both differences and similarities. The results confirm the raison d'être of the theory of human capital. According to this theory the labor market benefit of higher education is still indisputable.

Fortunately, the rising periods taken into account in the selection of study years were able to reduce the different causes of regional differences. In the last decade, however, there has been a rearrangement in the respondents' work-related value choices, which has not been shown markedly in the present study because the features of Nyíregyháza and the employment opportunities of the disadvantaged areas along the border show similar differences with the now measurable differences (unemployment, educational level, large disparities in average incomes, etc.) between the more developed and lagging regions of the country. These differences call for rapid, innovative solutions.

Studying characteristics of job satisfaction can therefore be an important basis and starting place for the planning of the necessary economic and social processes in the near future. It is in the interest of the national economy and the whole society to have a change and not a crisis in the new decade.

\section{References}

Bánfalvy, Cs. (2002). A munkanélküliség. Magvetö Könyvkiadó, Budapest.

Betlehem, J. (2012). Egészségügyi szakdolgozók humánerőforrás helyzetének főbb jellemzői 2012-ben. Népegészségügy, 90(2), 77-83.

Cannas, M., Sergi, B. S., Sironi, E., \& Mentel, U. (2019). Job satisfaction and subjective wellbeing in Europe. Economics and Sociology, 12(4), 183-196. doi:10.14254/2071789X.2019/12-4/11

Coleman, J. S. (1996). A társadalmi tőke. In: Lengyel György - Szántó Zoltán (eds.). A gazdasági élet szociológiája. BKE Szociológiai és SzociálpolitikaiTanszék, Budapest, 99-129.

Deutsch A., Fejes E., Kun Á., \& Medvés D. (2015). A jólétet meghatározó tényezők vizsgálata Egészségügyi Szakdolgozók körében. Alkalmazott Pszichológia, 15(2), 4971. doi:10.17627/ALKPSZICH.2015.2.49

E. Oswald, A. J. (1996): Satisfaction and comparison income. Journal of Public Economics, 61(3), 359-381.

Erdei, R., Barth, A., R. Fedor, A., \& Takács, P. (2018): Measuring the factors affecting health literacy in East Hungary - Health literacy in the adult population of Nyíregyháza city. Kontakt, 20(4), 375-380. https:// doi.org/10.1016/j.kontakt.2018.08.007

Fábián, G., Huszti, É., Hüse, L., \& Takács, P. (2018). Az életminőség Nyíregyházán. A nagymintás társadalomkutatás első négy hulláma a megyeszékhelyen. SzabolcsSzatmár-Beregi Szemle, 53(3), 83-102.

Fernández Puente, A. C., \& Sánchez-Sánchez, N.(2021). Understanding executive women's perspectives on job satisfaction and their different domains. Economics and Sociology, 14(1), 159-177. doi:10.14254/2071-789X.2021/14-1/11 
Frey, M. (1997). Nők a munkaerőpiacon In: K. Lévai and I. Gy. Tóth (eds.): Szerepváltozások. Jelentés a nök és férfiak helyzetéröl. Munkaügyi Minisztérium Egyenlő Esélyek Titkársága, TÁRKI, Budapest, 13-34.

Galasi, P., \& Körösi, G. (2002). Közelkép. Munkakínálat; Munkaerő kereslet. In.K. Fazekas (eds.): Munkaeröpiaci Tükör. MTA Közgazdaságtudományi Kutatóközpont, Országos Foglalkoztatási Közalapítvány, Budapest, 39-176.

Hajdu, G., \& Sik, E. (2016). A munkával kapcsolatos értékek a világban (1990-2014) és a mai Magyarországon. In. T. Kolosi, I. Gy. Tóth (eds.) Társadalmi Riport. TÁRKI, Budapest.

Herzberg, F. (1968). One More Time: How Do You Motivate Employees? Harvard Business Review, 46(1) 53-62.

Jin, J., J. Rounds (2012). Stability and change in work values: A meta-analysis of longitudinal studies. Journal of Vocational Behavior, 80(2), 326-339. doi:10.1016/j.jvb.2011.10.007

Láczay M. (2014). A szervezetfejlesztés és szervezeti kultúra kapcsolatának vizsgálata egy térség vállalkozásaiban, A Virtuális Intézetek Közép-Európa Kutatására Közleményei. Taylor Gazdálkodás- és Szervezéstudományi Folyóirat, 1-2(6), pp. 78-88.

Láczay, M. (2017). A humánerő fejlesztésének kérdőjelei a halmozottan hátrányos térségekben. A Virtuális Intézetek Közép-Európa Kutatására Közleményei. Taylor Gazdálkodás- és Szervezéstudományi Folyóirat, 9(2), 129-137.

Libicki, É., R., \& Fedor, A. (2020). A szubjektív egészségi állapot kutatási hátterének többszintü megközelítése a társadalmi egyenlötlenségek tükrében. Acta Medicinae Et Sociologica, 11(31), 13-25.

Locke, E. A. (1976). The Nature and Causes of Job Satisfaction. The Handbook of Industrial and Organizational Psychology, 1, 1297-1343.

Medgyesi M., \& Róbert P. (2000). A munkával való elégedettség nemzetközi összehasonlításban. In: T. Kolosi, I. Gy. Tóth, Gy. Vukovich (eds.) Társadalmi riport 2000. Budapest: TÁRKI, 591-616.

Móré, M. (2018). A foglalkoztatáspolitika helye, szerepe a társadalomban. In: Sebők, Marianna (szerk.) A munka világa a 21. század elején: Foglalkoztatáspolitikai és munkaerőpiaci kézikönyv. Budapest, Magyarország: SAXUM, 431, 31-50.

Németh A. (2013). Az egészségügyi dolgozók munkaelégedettségét befolyásoló tényezők, Növér, 26(4), 27-31.

Olson, M. (2003). Organisational Barriers to Professional Telework. In: Homework: Historical and Contemporary Perspectives on Paid Labor at Home, 215. p.

R. Fedor, A. (2015). Egyensúlyban? - A munkaerö-piaci karriertöl a familiarizmusig. Debrecen, Magyarország. Debreceni Egyetemi Kiadó, 252 p.

R. Fedor, A. (2018). Foglalkoztatási helyzetkép és a munkával való elégedettség jellemzői. Acta Medicinae et Sociologica, 27(9), 33-57. doi: 10.19055/ams.2018.9/27/4

R. Fedor, A., Toldi A. (2017). Labour market opportunities of women with young children after childbirth. Kontakt, 19(3), 236-243. doi: 10.1016/j.kontakt.2017.07.003

Rosen, S. (1998). Emberi tőke. In: Lengyel György - Szántó Zoltán (szerk.): Tőkefajták: a társadalmi és kulturális erőforrások szociológiája. Budapest. Közgazdaságtudományi Egyetem, Aula Kiadó, Budapest, 71-100.

Strauss, G. (1974). Job satisfaction, motivation, and job redesign. In: Strauss, G., Miles, R.E., Snow, C.C., Tannenbaum, A.S. (eds.), Organizational Behavior: Research and Issues: 19-49. Madison, WI: Industrial Relations Research Association.

V. Balla, P. (2021). Lehet-e a távmunka az új gyakorlat a foglalkoztatásban? A tudásháromszög szolgálatában I. Elöitéletesség nélkül - Szakmai tisztességgel (under appearance)

Varga, J., Hajdu, T., Hermann, Z., Horn, D. (2015). A közoktatás indikátorrendszere, 2015. MTA KRTK Közgazdaság-tudományi Intézet, Budapest. 
Warr, P. (1987). Work, Unemployment, and Mental Health, Clarendon Press, Oxford.

Wuthnow, R. (2008). The sociological study of values. Sociological Forum, 23(2), 333-343. doi: 10.1111/j.1573-7861.2008.00063.x.

\section{Databases}

Eurostat 2018 and 2013 - Personal well-being indicators (ilc_pwb)

Eurofound (2020), Living, working and COVID-19 dataset, Dublin, http://eurofound.link/covid19data

International Social Survey Programme: Work Orientation III - ISSP 2005

International Social Survey Programme: Work Orientations IV - ISSP 2015

Quality of Life in Nyíregyháza Household Panel (2018) 